\title{
En problematisering af samspillet mellem centrale pædagogiske principper på arkitektuddannelsen
}

Niels Grønbæk, arkitekt, ph.d. og lektor på Kunstakademiets Skoler for Arkitektur Design og Konservering i København, Institut 1, Institut for Bygningskultur og Studieafdeling 2.

Camilla Hedegaard Møller, arkitekt maa, mdl og ph.d.-studerende, Kunstakademiets Skoler for Arkitektur Design og Konservering i København, Institut 3, Institut for Planlægning.

\section{Reviewet artikel}

Ud fra John Deweys erfaringspædagogik, bygget op om begreberne erfaring, situation og samspil, undersøges aspekter af en strukturel adskillelse af målstyrede og projektbaserede undervisningspraksisser med arkitektuddannelsen på Kunstakademiets Skoler for Arkitektur Design og Konservering som eksempel på en uddannelse baseret på både et videnskabeligt og et kunstnerisk grundlag. Det diskuteres om den også konkret rumlige adskillelse af de to grundlags respektive pxdagogiske platforme $i$ henholdsvis kursusundervisning og projektundervisning er tilsigtet og hensigtsmæssig med særligt henblik på at opspore tiltag, der kan styrke uddannelsens forskningsbasering. I et bredere perspektiv pladerer artiklen for etableringen af fagstudiemiljøer til befordring af erfaringsdannelsen i samspilssituationer på tværs af grundlag - $i$ dette tilfxlde det kunstneriske og videnskabelige.

\section{Problemstilling}

Hvordan styrkes forskningsbaseringen af projektundervisningen på en kunstnerisk uddannelse? Vil en større bevidsthed om tilrettelæggelsen af undervisningens rumlige og sociale rammer kunne befordre erfaringsdannende samspil mellem målstyrede og projektbaserede undervisningspraksisser?

Arkitektuddannelsen på Kunstakademiets Arkitektskole (herefter KA) under Kunstakademiets Skoler for Arkitektur, Design og Konservering (herefter KADK) i København er en oplagt case for denne diskussion, eftersom uddannelsen pædagogisk set $\mathrm{i}$ princippet bygger på tilstedeværelsen af projektundervisning, der har det kunstnerisk arkitektoniske projektforslag som mål, og kursusundervisning, der har det som 
mål at bibringe et på forhånd bestemt læringsindhold. Hver side står for 30 af studieårets i alt 60 ECTS- point og kaldes følgelig 30/30-modellen. Første paragraf i skolens bekendtgørelse ${ }^{1}$ er baggrund for modellen:

"Formålet med arkitekturuddannelsen er på et kunstnerisk og videnskabeligt grundlag at kvalificere den studerende til beskxftigelse som arkitekt inden for den offentlige og private sektor."

Indførelsen af 30/30-modellen i 2008 havde netop til hensigt at styrke uddannelsens videnskabelige grundlag og den formelle akkreditering af uddannelsen som forskningsbaseret. Man byggede således reelt på den antagelse, at uddannelsens videnskabelige grundlag mere effektivt kunne styrkes gennem kursusundervisningen end gennem projektundervisningen. Det kan udledes, at det er blevet anset for relativt vanskeligere at styrke uddannelsens videnskabelige grundlag via den kunstnerisk orienterede projektundervisning. For så vidt har det kunstneriske og det videnskabelige hver sin pædagogiske platform i uddannelsen.

Denne artikel drejer sig imidlertid om samspillet eller mangel på samme mellem disse grundlag, idet der hidtil har været en tendens til at adskille de to grundlag pædagogisk. Arkitektuddannelsen har således været præget af vanskeligheder med at skabe pædagogisk sammenhæng mellem på den ene side projektundervisning som en åben erfaringsfremmende pædagogisk praksis, hvor målet opstår hen ad vejen, og på den anden side en målsætningspædagogik båret af idéen om transparens i læringsmålene. Denne dobbelte mangel på sammenhæng mellem projektundervisning og kursusundervisning, og mellem målstyrede og innovative undervisningselementer, er afsæt for denne artikel. ${ }^{2}$

Artiklen bygger på den antagelse, at arkitektuddannelsen har et stort potentiale som eksperimentarium for etablering af innovative samspil mellem tænkning på henholdsvis videnskabeligt og kunstnerisk grundlag. Det leder frem til følgende problemformulering: Hvordan kan samspillet mellem arkitektuddannelsens videnskabelige og kunstneriske grundlag stimuleres med henblik på videnskabelig styrkelse af det kunstnerisk innovativt orienterede projektarbejde, såvel som en styrkelse af en videnskabeligt orienteret kursusvirksomhed gennem berøring med en kunstnerisk

\footnotetext{
${ }^{1}$ Jf. Bekendtgørelse om arkitektuddannelsen ved Det Kongelige Danske Kunstakademis Arkitektskole og Arkitektskolen i Aarhus. (bachelor og kandidatuddannelsen) (2000).

${ }^{2}$ For at sikre en vis proportion i opfattelsen af den kritik, der vil blive fremført i artiklen, er det på sin plads at fremhæve, at Kunstakademiets Arkitektskole i den internationale benchmarking rapport Transforming Tradition fra 2006 fremhæves for følgende i den overordnede konklusion: "The expert-panel finds that the School of Architecture is producing graduates of a high quality. It is an ambitious school with quite a long standing reputation and a great potential to hold a major position in the European landscape of architectural schools." Transforming Tradition. International Benchmarking of the Royal Danish Academy of Fine Arts School of Architecture (2006), s. 15.
} 
innovativ tænkning? Spørgsmålets relevans angår således den mulige frigørelse af potentialer for en styrkelse af såvel den kunstneriske som den videnskabelige skabelse knyttet til arkitektuddannelsen. I videre forstand er artiklen orienteret mod at befordre innovative samspil på uddannelser, der foregår i krydsfeltet mellem flere grundlag - her mellem kunst og videnskab.

\section{Arkitektuddannelsen nu}

Arkitektuddannelsen er i udgangspunktet en kunstnerisk uddannelse vokset ud af Det Kongelige Danske Kunstakademi og orienteret mod arkitektfagets praktiske udøvelse. Overordnet er KA i dag organiseret i forskningsinstitutter og en række studieafdelinger, der varetager projektundervisningen på både bachelor- og kandidatniveau. Uddannelsesforløbet præges i løbet af de 5 år, det varer, af stadig større kompleksitet og faglig selvbestemmelse. Projektarbejdet, som er den primære undervisningsform gennem hele studiet, foregår i hovedsagen på studieafdelingerne. Undervisningsformen træner de studerendes selvstændige og kritiske tænkning. Samtidig mimer den på mange måder byggeriets indledende faser og er således direkte professionsrelevant. I bedste fald er det dog også i projektudviklingen, at de studerende kan opnå at overskride både egne og andres forestillinger om, hvad der er muligt, og om hvordan fremtidens arkitektur, byer og landskaber kan se ud. Dette er langtfra en selvfølge, men KA's afgangsudstillinger minder til stadighed om, at fremtiden kan tænkes og formes på nye måder, rumligt såvel som socialt.

Undervisningen på studieafdelingerne er i hovedtræk 'tegnebordssamtalen', en ugentlig vejledningssamtale mellem én studerende og vedkommendes vejleder, der ofte er praktiserende arkitekt med skolearbejdet som en slags bibeskæftigelse. Med jævne mellemrum fremlægger hver studerende sit projektarbejde i plenum. Her kritiseres de enkelte projekter gennem en i princippet åben faglig diskussion, der inddrager et større hold studerende. Vejlederne stiller typisk en fælles, fasedelt opgave for et mindre hold - på kandidatniveauet med relativt åbne læringsmål. Opgaven besvares oftest individuelt. På første år er opgaver nøje defineret af vejlederne, hvor afgangsopgaven på 10. semester (svarende til specialet) udvikles selvstændigt af den enkelte studerende. Den afsluttende eksamen - 'afgangen' - er en både mundtlig og karaktermæssig bedømmelse af afgangsprojektet.

Studierne på studieafdelingerne foregår på 'tegnesalen', der er det sted, hvor de studerende opholder sig mest og i det hele taget er det rumligt pædagogiske og studiemiljømæssige særkende ved KA. Det er nærmest utænkeligt at gennemføre uddannelsen uden at være dagligt til stede på skolen. Indretningen af 'tegnesale' skaber således i vid udstrækning rammer for en socialt orienteret erfaringspædagogik bygget op om projektarbejdet. 
Den forskningsbaserede undervisning, som især institutterne varetager, har typisk form af obligatoriske eller valgfrie kurser og foredragsrækker og udbydes oftest uafhængigt af afdelingernes projektundervisning.

\section{Adskillelsens problem i et tidsperspektiv}

I dette afsnit opspores og dokumenteres en manglende sammenhæng mellem kursusundervisning og projektundervisning på KA på baggrund af skolens senere udvikling.

Arkitektskolens nære forbindelse til praksis blev gennem det 20. århundrede forankret i uddannelsens organisering omkring en række professorer udpeget blandt dansk bygningskunsts fremmeste praktikere. Hvor den deraf følgende kunstneriske orientering af uddannelsen havde tabt terræn under påvirkning fra den venstreorienterede ideologiserings epoke i 70'erne, havde den i løbet af et par årtier frem mod årtusindskiftet atter opnået noget nær selvfølgelighed. I dag er det kunstneriske igen, hvis ikke omstridt, så dog genstand for jævnlige problematiseringer. I rapporten Transforming Tradition (2006), udfærdiget i sammenhæng med en international evaluering af KA i 2005, har man dog noteret sig den enkelte studerendes kunstneriske udvikling som et bærende karakteristikum for uddannelsen:

"Progression seems first and foremost to be artistic in nature. The tradition of 'learning by doing' permeates the school's culture. There is no strong tradition for obtaining knowledge by reading, learning a specific syllabus or doing written assignments related to the foundational disciplines of architecture."(TransformingTradition, 2006:16).

Konsekvensen af bl.a. denne iagttagelse blev anbefalingen af ligeværdighed på bachelorniveau mellem undervisning orienteret mod henholdsvis 'knowledge' og 'practice'. Denne anbefaling er i mindre grad slået igennem på kandidatniveauet. I 1999 indførtes opdelingen af skolen i institutter og studieafdelinger. I kraft af Bologna-deklarationen blev studiet opdelt i 3+2+3 (bachelor, kandidat og ph.d.) i 2002. ${ }^{3}$ I 2007 indførtes 7-trins karakterskalaen. Samme år udgav Danmarks Evalueringsinstitut en introduktion til kompetencebegreber på KA ${ }^{4}$, hvor kompetencetænkningen omtales som en pædagogisk nyorientering - fra fokus på input, til fokus på den studerendes faktiske udbytte af et forløb. Med den såkaldte 'kvalifikationsramme' introduceredes også på KA den velkendte skelnen af læringsudbytter i viden, færdigheder og kompetencer. I skolens kvalifikationsramme ${ }^{5}$ er kategorierne beskrevet for henholdsvis 1. år, bachelor- og kandidatstudiet. Inden for kategorierne anviser ram-

\footnotetext{
${ }^{3}$ Jf. Kunstakademiets Arkitektskoles historie: http://www.karch.dk/dk/Menu/Om+skolen/Historie

${ }^{4}$ Jf. Kompetencebegreber, en introduktion udarbejdet til Kunstakademiets Arkitektskole (2007:7)

${ }^{5}$ Kvalifikationsramme (2007).
} 
men progression gennem studiet, men ikke eksplicit en sammenhæng mellem kategorierne ud over deres sideordning. Også kvalifikationsrammen har således bidraget til opdeling - ved at tillade en deling der gav institutterne ansvar for vidensdelen og afdelingerne ansvar for udvikling af færdigheder og kompetencer.

KA har netop gennemført en fusionsproces med Danmarks Designskole og Kunstakademiets Konservatorskole, (tilsammen KADK) og har i 2011 fået en samlet professionel bestyrelse. Samtidig er institutionen i gang med en faglig omstruktureringsproces, der på KA har en styrket sammenhæng mellem forskning og undervisning som en del af visionen. I oplægget fra skolens strategiske ledelse til en ny faglig struktur på KA, beskrives den eksisterende struktur bl.a. således:

"En styrke ved den nuværende organisation er, at de studerende har en veldefineret base (en slags familie), hoor de i princippet kan tilbringe hele deres studietid, hoilket giver mulighed for fordybelse. En svaghed er, at forskningsenhederne og studieafdelingerne er adskilte, hvorfor den forskningsbaserede, tværgående undervisning er vanskelig at indpasse i projektundervisningen. Denne sidstnævnte undervisningsform mangler til gengæld ofte en forskningsdimension, hvilket især viser sig som et problem på kandidatniveau." (Strateginotat. 2012, s. 8).

Som strukturelt svar på disse udfordringer, foreslår KADK's strategiske ledelse, at institutter og afdelinger samles i færre og større enheder, der skal stå for både forskning, kurser og projektundervisningen. De studerende på KA har i et høringssvar ${ }^{6}$ udtalt bekymring i forhold til studieafdelingernes - 'familiens' - forsvinden, idet det forekommer, at man skiller sig af med det velfungerende og beholder det, der ikke fungerer. De studerendes tilkendegivelser i undervisningsevalueringer fra 2011 og $2012^{7}$ understøtter yderligere synspunktet om manglende sammenhæng.

\section{Adskillelsens problem set indefra og udefra}

De studerende på Arkitektskolen sætter projektundervisningen ${ }^{8}$ og den personlige vejledning ved tegnebordene højt, hvilket svarer til en udbredt opfattelse på skolen ${ }^{9}$ af, hvilken pædagogisk metode der særligt kendetegner den. Den udbredte opbakning medvirker imidlertid til at skabe yderligere afstand til kursusundervisningen med det resultat, at der i projektundervisningen kan være en tendens til, at de studerende dyrker personlige skaberinteresser på bekostning af indøvelsen i at skabe synteser under inddragelse af eksisterende viden og samfundsrelevante problemstillin-

\footnotetext{
${ }^{6}$ Jf. KA's studerendes høringssvar til rektor vedr oplæg til ny faglige struktur (2012).

7 Jf. Analyse af undervisningsevaluering på afdelinger_2010 (2011) og Notat: Hovedpunkter i undervisningsevaluering 2011 - samlet analyse (2012).

${ }^{8}$ Jf. Analyse af undervisningsevaluering på afdelinger_2010 (2011).

${ }^{9}$ Jf. Strateginotat. Strategisk Ledelse: Ny faglig struktur. Det Kongelige Danske Kunstakademis Skoler for Arkitektur, Design og Konservering (u.år / 2012).
} 
ger. Arkitekten Gerard Reinmuth har således i forbindelse med et gæsteprofessorat på Arkitektskolen i Aarhus i 2009-10 fundet anledning til at påpege, at projektundervisningen, som den aktuelt praktiseres på arkitektskolerne i Danmark, populært sagt er en slags 'selvrealiseringskuvøse' (Reinmuth, 2011). Denne kritik finder yderligere støtte i den amerikanske pædagogiske tænker John Deweys allerede i trediverne fremførte kritik af visse progressive skolers dyrkelse af den enkeltes frihed (Dewey, 1938).

Hvorom alting er, synes der på KA at tegne sig en adskillelse mellem en åben erfaringsfremmende pædagogisk praksis, hvor målet opstår undervejs, over for en målstyret og mere curriculumorienteret pædagogik, hvor det hensigtsmæssige udbytte af læreprocessen fastlægges på forhånd og undervisningens effektivitet søges direkte opgjort i forhold til intenderede læringsmåludbytter. Denne adskillelse blev ikke gennemtænkt pædagogisk ved introduktionen af 30/30-modellen men tværtimod knæsat af den. Denne fordeling taler for at Reinmuths kritik af projektundervisningen stadig er berettiget, ligesom den adskillelse, der følger af 30/30-fordelingen, gang på gang udsættes for de studerendes kritik. Her er det, at Dewey inspirerer til bestræbelser på at forvandle en bekvem adskillelse til et dynamisk samspil. Og det begrunder yderligere relevansen af artiklens problemformulering.

\section{Ad Dewey}

Dewey bestemmer i Experience and Education, hvad han kalder 'erfaringens to dimensioner' som princippet om erfaringens kontinuitet og samspil. Princippet om 'erfaringens kontinuitet' beror først på, at erfaringer sætter sig i kroppen i selve erfaringens øjeblik og dernæst på kroppens evne til at fastholde det erfarede. Det er kroppens hukommelse, der muliggør erfaringernes sammenhæng over tid. En ny erfaring kan forskyde tidligere erfaringer og derfor i en vis forstand også sit eget grundlag og den kan give anledning til nye erfaringer. Dewey taler her om 'vækst' som vækst i erfaringernes mængde og potentiale for nye erfaringer, nye horisontudvidelser. Men det er ikke alle erfaringer, der er konstruktive. Erfaringer kan også være destruktive både for én selv og andre. Princippet om erfaringens kontinuitet indebærer således både, at erfaringer uvægerligt påvirker (alle) andre erfaringer bagud og ind i fremtiden, og, i sammenhængen vigtigere, at denne påvirkning kan kultiveres gennem vejledning. Denne vejlednings hvorledes fastholdes $\mathrm{fx}$ med begreber som opdragelse og oplæring.

Erfaringens anden dimension - 'samspil' - bestemmer Dewey som samspillet i selve erfaringsprocessen mellem ydre og indre vilkår. De indre vilkår knytter sig til individets anlæg, vaner og erfaringer. Om de ydre vilkår, der kan forstås som et udvidet og mangefacetteret kontekstbegreb, siger han: 
"[...] the phrase "objective conditions" covers a wide range. It includes what is done by the educator and the way in which it is done, not only words spoken but the tone of voice in which they are spoken. It includes equipment, books, apparatus, toys, games played. It includes the materials with which an individual interacts, and, most important of all, the total social set-up of the situations in which a person is engaged." (Dewey, 1938, s. 43).

For Dewey har også samspillet to dimensioner. At der snarere er tale om to dimensioner, og ikke en enkelt dimensions 'diametrale' retninger, følger af, at de ydre objektive og de indre vilkår må tænkes som distinkte og reelt adskilte forud for selve den relationsproces, der foregår i samspillet. Netop ved at bringe det på forhånd adskilte sammen i et samspil, indtræffer erfaringens begivenhed. Dewey betegner samspillets konkrete begivenheder 'set udefra' med begrebet 'situation'. Samspillet kan således skelnes i et ydre og et indre aspekt som henholdsvis 'situationen' og 'erfaringen'.

Når det gælder de med bestemte hensigter indrettede og institutionaliserede erfarings- og læringsrum såsom skoler, bør de erfaringsskabende situationer grundlæggende være sociale. I dette, at de bør være sociale ligger, at de for Dewey ikke nødvendigvis er det. Således kritiserer han den traditionelle skole for, med sit ideal om 'ro i klassen', at dyrke en disciplinering, der direkte begrænser og modgår en socialt dynamisk erfaringspædagogik. For Dewey gælder det tværtimod om at skabe rum for læreprocesser, der er sociale i den forstand, at de befordrer en gensidig erfaringsfremmende udveksling mellem lærere og studerende og mellem studerende indbyrdes. Det er altså for Dewey absolut hensigtsmæssigt at befordre en vis social dynamik i læringsrummene, men han går længere end som så:

"Experience does not go on simply inside a person. It does go on there, for it influences the formation of attitudes of desire and purpose. But this is not the whole of the story. Every genuine experience has an active side which changes in some degree the objective conditions under which experiences are had."(Dewey, 1938, s. 39).

Erfaring opstår i samspillet mellem ydre og indre vilkår, og samspillet har virkninger begge veje: Udefra og ind og indefra og ud. Men hvor sætter disse ændringer indefra og ud sig? De sætter sig i "the total social set-up". Definerer man studiemiljø som et sådant 'social set-up, rejser der sig straks spørgsmål om indretningen og befordringen af pædagogisk effektive studiemiljøer.

\section{Diskussion og konklusion}

Bygger en uddannelse på flere grundlag - i tilfældet KA et kunstnerisk og et videnskabeligt - kan en strukturel deling af grundlagene, så de fx knyttes til hhv. kursusundervisning og projektundervisning, føre til manglende pædagogisk sammenhæng i uddannelsen. Man har været opmærksom på problemet på KA og også i løbet af 
det seneste tiår søgt at reducere det - dog væsentligst ved at kompensere gennem at ændre på, hvad de studerende forventes at lære. Der har yderligere på det seneste været gjort et seriøst arbejde for at løfte det pædagogiske refleksionsniveau på skolen. Således har skolen tilbudt et adjunktpædagogikum siden 2009. Endelig er det en central hensigt med den igangværende strukturomlægning at skabe bedre sammenhæng i uddannelsen Og målt på sin hensigt er den en del af svaret på det forste af artiklens indledende spørgsmål: Hvordan styrkes forskningsbaseringen af projektundervisningen på en kunstnerisk uddannelse?

Det hjælper at skabe pædagogisk og administrativt hensigtsmæssige enheder, men for at fungere pædagogisk er det afgørende, at disse ændringer i de ydre vilkår slår igennem i hvad Dewey kalder "...the total social set-up of the situation in which a person is engaged" (Dewey, 1938, s. 43). Den nye struktur vil skabe administrative og pædagogiske rammer, hvor uddannelsens to grundlag vil kunne bringes i bedre kontakt. Her er det de mulige positive effekter af at gennemtænke et aspekt af uddannelsens rumlige og sociale indretning, der har vores særlige bevågenhed, nærmere bestemt en overvejelse over befordring af dannelsen af i pædagogisk forstand hensigtsmæssige studiemiljøer. Det leder frem til det andet indledende spørgsmål: Hvilken betydning kan de rumlige og sociale dimensioner have på samspillet mellem forskellige læringssituationer?

Vanskeligheden ved målstyring af projektarbejdet er groft sagt, at udfaldsrummet må være stort, hvis man på kandidatniveau ønsker at træne de studerende til egentligt innovativt arbejde. Her kan styringen med fordel angå begyndelsesbetingelserne snarere end målet - fx gennem inddragelse af forskningsbaseret viden og samfundsrelevante problemstillinger $\mathrm{i}$ det indledende individuelle arbejde med at udvikle projektets program. Afgørende er imidlertid projektformatets fordele som både ramme og katalysator for erfaringer med innovative designprocesser. Teoretiseres Gerard Reinmuths kritik med Dewey, kan man sige, at projektundervisningen for tiden har for godt fat i den enkeltes 'indre vilkår' som kilde til motivation. Det ligger derfor ligefor, ved siden af den pædagogiske bestemmelse af de ydre vilkår, der knytter sig til 'tegnesalen', at skærpe vejledningspraksis, så den pædagogiske tilrettelæggelse af de ydre vilkårs rolle i erfaringsdannelsen styrkes. Her trækker 'tegnesalen' i udgangspunktet i en positiv, ydre retning, væk fra tendenser i retning af tegnebordet som selvrealiseringskuvøse jf. Reinmuths kritik. Iflg. Dewey er de erfaringer, studiemiljøet skaber rum for, imidlertid ikke nødvendigvis gode. Det vender vi tilbage til. Både de studerende og de undervisere, der er knyttet til studieafdelinger, er meget opmærksomme på 'tegnesalen' som grundlaget for uddannelsens helt centrale "total social set-up". Den har afgørende positiv indflydelse på skabelsen af et studiemiljø, men hvor den yderligere er hjemsted for en studieafdeling, er den også den ramme, der sikrer, at der kan opstå et særligt fagligt studiemiljø, en studiekultur 
- det KA-ledelsen kalder 'en slags familie'. At 'tegnesalen' kan være mulighedsbetingelse for sådanne 'familier' peger på, at den i Dewey'sk forstand selv er en del af 'en krop, der husker' og dermed befordrer fastholdelsen af en anden 'erfaringens kontinuitet' end den, der bæres af menneskekroppe, en der nemlig sætter sig i de 'ydre vilkår'. Derfor kan 'tegnesalen' betragtes som ramme om en egentlig og i sig selv lærende enhed - på KA for tiden kaldet en studieafdeling. Hvis en sådan enhed lukker sig om sin egen metode og sin egen kultur - idet de indre vilkår har opnået en vanemæssig tæthed - vil den studerende, der har knyttet sig og sit projektarbejde til en sådan enhed, risikere at effektuere en dobbelt eller forstærket udelukkelse af potentielt nye, produktive impulser fra ydre vilkår. Mekanisk udtrykt fører et stort sammenfald mellem en studerendes og en afdelings indre vilkår til et lille eller begrænset samspil. Sagt på en anden måde: Det gensidigt påvirkende samspil mellem ydre og indre vilkår kan i princippet konvergere mod et fuldstændigt sammenfald. Det var derfor, vi fandt anledning til at bemærke, at tegnesalen kan befordre uhensigtsmæssige erfaringer. Hvis omvendt en studieenhed både opnår at etablere en erfaringens kontinuitet fastholdt $i$ et fagstudiemiljø og så at sige holder sit rum - i dette tilfælde 'tegnesalen' - åben for nye fx forskningsbaserede impulser, så vil den også styrke sin 'egen' evne til at lære. Og i sammenhængen er det ad sådanne åbninger, det videnskabelige og forskningsbaserede kan optages i den særlige erfaringens kontinuitet, en given studiekultur udgør. En måde at styrke forskningsbaseringen af projektundervisningen knyttet til en kunstnerisk uddannelse på er altså at give rammer for tilvejebringelsen af studiemiljøer, fx i form af 'tegnesale', og at løfte studiemiljøet til en egentlig faglig enhed - ikke (blot) administrativt, men potentielt som en kulturel enhed - "a total social set-up" - hvis kultur på den ene side står og falder med sin evne til at ophobe og sikre erfaringens kontinuitet og på den anden side sin evne til at lære. Imødekommende Reinmuths og andres kritik gennem en styrkelse af projektundervisningen knyttet til et fagstudiemiljø må dette med pædagogisk overlæg holde sig åbent for hensigtsmæssige opdragende effekter i retning af en styrkelse af kvaliteten i samspillet mellem indre og ydre vilkår, hvad enten der ses fra en studerendes eller fra en 'lærende studieenheds' perspektiv.

Omvendt har kursusundervisningsforløb på fx arkitektuddannelsen det problem, at de kun er af få ugers varighed. Der opbygges så godt som intet fagstudiemiljø omkring dem, og det lidt, der måtte etableres, opløser sig ved kursets afslutning. Kurser må altså forlade sig på de spor, de efterlader sig i den erfaringens kontinuitet, de studerende bære med sig. Men her er problemet yderligere, at kursusundervisningen som nævnt ofte er en curriculumundervisning med begrænsede muligheder for at skabe egentlige kompetencer, dvs. opnå den fortrolighed med stoffet gennem en erfaringsdannelse, der kun kan indtræffe gennem konkret brug af det doserede stof. Teoretiseret med Dewey kan vanskelighederne med at gøre kursusundervisningen kompetenceskabende begrundes i, at den ikke i tilstrækkelig grad inddrager den 
enkeltes 'indre vilkår'. Derfor bliver læreprocessen en-vejs i stedet for social. Og derfor bliver læringsmålsudbytter ikke i tilstrækkelig grad indlejret i 'erfaringens kontinuitet', fordi de simpelthen er for isolerede fra de indre vilkår og derfor i utilstrækkeligt omfang hægter sig på den studerendes forudgående og kommende erfaringer. Her har studiemiljøer, som dem der kendes på KA's studieafdelinger, knyttet til en erfaringsdannende projektundervisning, meget at tilbyde kursusundervisningen.

Det er jo imidlertid ikke hensigten med denne artikel at styrke kursus- og projektundervisning hver for sig. Den konklusion, vi når frem til, er, at begge disse pædagogiske platforme må integreres i en og samme 'de ydre vilkårs erfaringskontinuitet', et og samme studiemiljø. Her melder der sig en række mere konkrete spørgsmål, som vi ikke påtager os at svare på i denne sammenhæng. Disse spørgsmål angår fx 'kritisk masse': Kan der siges noget generelt om hensigtsmæssige tærskelværdier i et studiemiljø - fx individ, nærmeste studiekammerater, holdstørrelser, fagstudiemiljø (som fx studieafdelingerne på KA), studiemiljø, institution, fag? Andre hermed forbundne spørgsmål angår fx pædagogisk hensigtsmæssige rumlige indretninger, men i det hele taget mere præcise overvejelser over de pædagogiske påvirkningspotentialer, der kan udgå fra de ydre vilkår, Dewey beskriver. Ikke mindst kunne disse spørgsmål dreje sig om, hvordan ethvert stratum af erfaringskontinuitet kan holdes åbent og lærende gennem den aktive opsøgning af samspil med stedse foranderlige ydre vilkår.

Niels Grønbæk er arkitekt, ph.d. og lektor på Kunstakademiets Arkitektskole i København, hoor han er tilknyttet Institut 1, Institut for Bygningskultur og Studieafdeling 2. Niels har afgang fra Kunstakademiets Arkitektskole i 1995, har undervist på Arkitektskolen siden 1997, forsvarede i 2008 ph.d.afhandlingen For det kommende i det tidlige og afsluttede i 2010 Arkitektskolernes Pædagogikum. Sideløbende med undervisning og forskning har Niels deltaget $i$ interne og eksterne udstillings- og konkurrenceprojekter med både tekster og forslagsstillende bidrag. Niels' forskningsfelt er arkitekturen som en $i$ ontologisk forstand miljøorienteret (jf. fr. mi-lieu) praksis; Og i forlængelse heraf: Miljø; nærværsfilosofisk kritik; atmosfære (Böhme); byen som fortrolighedsfelt; det offentlige rums performativitet; sammenhænge mellem arkitektur og lovgivning.

Camilla Hedegaard Møller er arkitekt maa, mdl og ph.d.-studerende på Kunstakademiets Arkitektskole i København, hvor hun er tilknyttet Institut 3, Institut for Planlagning, ved Center for Byrumsforskning og Center for Idræt og Arkitektur. Camilla har afgang fra Kunstakademiets Arkitektskole i 2001, fik derefter Statens Kunstfonds 2-årige igangsætningsstipendium og arbejdede frem til 2012 på private tegnestuer med primært landskabsarkitektur, planlægning og senest særligt integreret kunst, og sideløbende som timelærer på Arkitektskolen tilknyttet Studieafdeling 1 og 2. Aktuelt har hun afsluttet Arkitektskolernes Pædagogikum og har påbegyndt ph.d.-projektet Metodeudvikling i landskabsarkitekturdisciplinen. 


\section{Litteratur}

Analyse af undervisningsevaluering på afdelinger 2010 (2011). Kan rekvireres fra KADK's studieadministration.

Bekendtgørelse om arkitektuddannelsen ved Det Kongelige Danske Kunstakademis Arkitektskole og Arkitektskolen i Aarhus. (bachelor og kandidatuddannelsen) (2000). København: Kulturministeriet.

Dewey, J. (1938). Experience and Education. Indianapolis: Kappa Delta Pi (The 60th Anniversary Edition, 1998). [Da. udg.: Dewey, J. : Erfaring og opdragelse, København, Christian Ejlers' Forlag (6. oplag på dansk, 2005)]

KA's studerendes høringssvar til rektor vedr. oplæg til ny faglige struktur (2012). Kan rekvireres via KADK's studieadministration.

Kvalifikationsramme (2007). København: Kunstakademiets Arkitektskole.

http://www.karch.dk/dk/Materiale/Files/Officielle+dokumenter/Kvalifikationsr amme_skema.pdf (tilgået 26.08.13)

Kompetencebegreber, en introduktion udarbejdet til Kunstakademiets Arkitektskole (2007). Danmarks Evalueringsinstitut (Kan rekvireres fra Danmarks Evalueringsinstitut).

Kunstakademiets Arkitektskoles historie:

http://www.karch.dk/dk/Menu/Om+skolen/Historie (tilgået 26.08.13)

Notat: Hovedpunkter i undervisningsevaluering 2011 - samlet analyse (10. maj 2012). Kan rekvireres via KADK's studieadministration.

Reinmuth, G. (2011). Context 1 - Architectural Education in Denmark. I: Gerard Reinmuth (Ed.), A Beaux Arts Education for the 21st Century - Aarhus Documents 01. Copenhagen: The Architectural Publisher B.

Strateginotat. Strategisk Ledelse: Ny faglig struktur. Det Kongelige Danske Kunstakademis Skoler for Arkitektur, Design og Konservering (u.år / 2012): http://studyarch.files.wordpress.com/2012/11/fagligstrategi_strategiskledelse_0 9112012.pdf (tilgået 26.08.13)

Transforming Tradition. International Benchmarking of the Royal Danish Academy of Fine Arts School of Architecture (2006). The Danish Evaluation Institute: http://www.eva.dk/projekter/2005/international-benchmarking-afkunstakademiets-arkitektskole (tilgået 26.08.13) 